\title{
Restoration of Cymodocea nodosa seagrass meadows through seed propagation: germination in vitro, seedling culture and field transplants
}

\author{
Maite E. Zarranz ${ }^{1,2}$, Nieves González-Henríquez², \\ Pilar García-Jiménez ${ }^{1}$ and Rafael R. Robaina ${ }^{1, *}$ \\ ${ }^{1}$ Departamento de Biología, Facultad de Ciencias del Mar, \\ Universidad de Las Palmas de Gran Canaria, 35017 Las \\ Palmas de Gran Canaria, Canary Islands, Spain, \\ e-mail: rrobaina@dbio.ulpgc.es \\ 2 Instituto Canario de Ciencias Marinas, Muelle de Taliarte, \\ 35200 Telde, Gran Canaria, Canary Islands, Spain \\ * Corresponding author
}

\begin{abstract}
Cymodocea nodosa, a marine angiosperm, an ecosystem engineer in the Mediterranean Sea and the Northwest Atlantic Ocean; however, as in other seagrasses meadows worldwide, the swards are actually declining due to increasing human pressures. Hence, we have developed an effective propagation methodology that provides $C$. nodosa seedlings for seagrass meadow restoration and conservation. This method consists of: i) germination of wild-collected seeds under hyposaline conditions, ii) acclimation of germinated seedling in tanks $\left(1.6 \mathrm{~m}^{3}\right)$ until there are two shoots per seedling ( $\sim 30$ days), and iii) transplantation of acclimated seedlings to the field in dense groups. Our field outplants withstood herbivore activity and physical disturbance during the winter season, and propagated vegetatively, resulting in the spread and establishment of a new patch that has persisted for nine months.
\end{abstract}

Keywords: acclimation; germination; hyposalinity; restoration; seagrasses.

\section{Introduction}

Concern has arisen over the decline of seagrass ecosystems worldwide as a result of adverse human activities in coastal areas (Walker and McComb 1992, Duarte et al. 2004, Orth et al. 2006, Duarte and Gattuso 2008, Hughes et al. 2009). Restoration and mitigation programs have been carried out since the mid-20th century (Addy 1947, Phillips 1974, Gordon 1996, Fonseca et al. 1998, Johansson and Greening 2000) using plant material collected from donor meadows (Orth et al. 1999, Heidelbaugh et al. 2000, Van Keulen et al. 2003, Paling et al. 2007, Park and Lee 2007). Because of the logistical burden associated with moving mature plants, the use of seeds and seedlings germinated in vitro is widely considered to be a more cost-effective alternative (Thorhaug 1985, Orth et al. 1994, 2000, 2009, Balestri et al. 1998, Kirkman 1998, Harwell and Orth 1999, Granger et al. 2002, Pickerell et al. 2005, Ailstock and Shafer 2006). This method is also likely to avoid damage to donor meadows from which planting units (comprising adult plants) are extracted (Christensen et al. 2004, Seddon 2004); transplanting seeds and seedlings also increases genetic variability in the receiving population that is to be restored or replanted (Waycott 1995, Williams and Orth 1998, Procaccini and Piazzi 2001, Reusch 2002).

The seagrass Cymodocea nodosa (Uchria) Ascherson forms dense, shallow water meadows (between 2 and $35 \mathrm{~m}$ deep) across the Mediterranean Sea and the Northwest Atlantic Ocean, including the Canary Islands (Reyes et al. 1995, Pavón-Salas et al. 2000, Alberto et al. 2008, Cunha and Araújo 2009). This marine angiosperm produces permanent seed banks throughout the year (Caye and Meinesz 1985, Caye et al. 1992, Terrados 1993, Reyes et al. 1995), but germination rates in nature may be variable. Pirc et al. (1986) and Reyes et al. (1995) reported germination rates as high as $50 \%$, but sometimes the rate is zero (Caye and Meinesz 1985); moreover, once seeds have germinated, their fate is mixed, and actual recruitment may be low (Caye and Meinesz 1986, Buia and Mazzella 1991, Terrados 1993, Reyes et al. 1995).

The sensitivity of this species to human impacts has been documented in several studies (Terrados and Ross 1995, Vergara-Martín et al. 2005, Fernández-Torquemada and Sánchez-Lizaso 2006), and a restoration protocol for conservation is urgently required. To this end, two studies have been performed to transplant Cymodocea nodosa adult plants from donor to recipient meadows (Curiel et al. 2003, Ruiz de la Rosa et al. 2006), but there have been no attempts to transplant seedlings.

Given the fragility of Cymodocea nodosa in the face of human impacts, and its low germination and seedling survival rates in nature (Caye and Meinesz 1985, Buia and Mazzella 1991), we believe that increasing germination potential and seedling survival would be an appropriate strategy for the conservation of this species and its habitat. In this study, we developed a methodology for propagation of $C$. nodosa seeds under laboratory conditions, the acclimation of seedlings to enhance biomass development, and outplanting in the wild under prevailing conditions ensuring enhanced survival rates. This methodology provides seedlings that might be employed for the restoration of small but strategically important degraded areas, or to improve the conservation of established meadows by introducing genetic variation. 


\section{Materials and methods}

\section{Seed collection and culture methods}

The seeds used in this study were collected by SCUBA diving (May 2007) in a Cymodocea nodosa meadow located off Juan Grande on the southeastern coast of Gran Canaria $\left(27^{\circ} 45^{\prime} 45.48^{\prime \prime} \mathrm{N} ; 1^{\circ} 33^{\prime} 04.01^{\prime \prime} \mathrm{W}\right.$, Spain). Seeds were found either on the surface of the seafloor or buried a few $\mathrm{cm}$ beneath the sediment. Once collected, seeds were placed in a nylon net $(0.2-\mathrm{mm}$ mesh), which kept them wet during transfer to the laboratory (within $2 \mathrm{~h}$ of collection).

To prevent overgrowth by epiphytes, seeds were gently cleaned with a tooth brush and then submerged for 10 min in a $10 \%(\mathrm{v}: \mathrm{v})$ commercial bleach solution made up in autoclaved seawater (a drop of Tween 80 was used as surfactant). Seeds were then washed three times in autoclaved seawater. Culture vessels (Magenta ${ }^{\mathrm{R}}$ - G7 $300 \mathrm{ml}$ Sigma Co., Chicago, IL, USA) were filled with $40 \mathrm{cc}$ of autoclaved sand and $200 \mathrm{ml}$ of liquid culture medium. We used PES culture medium (Provasoli 1968), but substituted ammonium for nitrate and mono-potassium phosphate for glycerol phosphate, based on previous experience with Cymodocea nodosa explant cultures (see García-Jiménez et al. 2006). The salinities of the seawater and culture medium in culture matched ambient seawater (36.6 psu), except where otherwise stated.

Cultures in the laboratory were placed inside a growth chamber at $24^{\circ} \mathrm{C}$, with a 16:8 light:dark photoperiod and $30 \mu \mathrm{mol}$ photons $\mathrm{m}^{-2} \mathrm{~s}^{-1}$ irradiance at the level of the culture vessels.

\section{Induction of germination}

Hyposaline shock was used to induce germination. This treatment facilitates the imbibition of water needed for seed germination (Caye and Meinesz 1986, Caye et al. 1992). Seawater diluted with double distilled water was used to achieve the different salinity levels: 5, 11 and 18 psu, while 36 psu was used as a control treatment (Robaina et al. 1990a,b). Thirteen culture vessels with two seeds in each (i.e., 26 seeds per treatment) were used for each treatment to determine the effects of hyposaline treatments on germination. Thirty days (based on preliminary experiments) after hyposalinity shock, all seeds and seedlings were transferred to $36.6 \mathrm{psu}$ medium to acclimate them to ambient salinity, and three different stages of development were monitored: stage I, germinating seeds (Figure 1A); stage II, stage with emergent green cotyledon (Figure 1B), and stage III, development of first new leaves (Figure 1C). These three stages of development extended over three months following germination induction.

\section{Acclimation of seedlings}

All viable seedlings that had reached stage III after the induction procedure were placed into holding tanks $\left(1.6 \mathrm{~m}^{3}\right)$ with sand covering the bottom (ca. 10\% of the total volume, $15 \mathrm{~cm}$ depth, no nutrients added) under open, continuous seawater flow, at an average temperature of $21^{\circ} \mathrm{C}$ and an average irradiance of $60 \mu \mathrm{mol}$ photons $\mathrm{m}^{-2} \mathrm{~s}^{-1}$ (Figure 1D). Leaf and root growth and shoot and root emergence were monitored fortnightly $(n=30)$ while plants were in the holding tanks (45 days) prior to transplantation to the field.

\section{Transplants of developed seedlings to the field}

Once plants had developed sufficient roots and shoots for transplantion (30-45 days), they were transferred to the field. Two pilot transplant treatments (May 2008) were compared: i) seedlings scattered on nylon nets tied with thread ( $20 \times 20 \mathrm{~cm}$ nets with 20 sown seedlings in each, $\mathrm{n}=60$, density $=500$ seedlings $\mathrm{m}^{-2}$ ), and ii) seedlings clustered in biodegradable trays made of compressed coconut fiber dust (trays hereafter), which allowed a healthy root growth in 12 compartments of $3 \times 3 \times 5 \mathrm{~cm}$, with three seedlings per compartment and up to 36 seedlings per tray, $n=108$, density $=$ 3333 seedlings $\left.\mathrm{m}^{-2}\right)$. A set of seedlings $(\mathrm{n}=76)$ was planted directly in the sediment; $\left(\right.$ density $=3377$ seedlings $\mathrm{m}^{-2}$ ). The nylon nets and trays were anchored using metal staples. For these pilot transplanting experiments, a sheltered location (6 $\mathrm{m}$ depth, along the edges of a natural meadow, $27^{\circ} 59^{\prime} 20.44^{\prime \prime} \mathrm{N} ; 5^{\circ} 22^{\prime} 12.45^{\prime \prime} \mathrm{W}$, Gran Canaria, Spain) was selected to improve chances of establishment and for monitoring purposes. Over nine months, we monitored $\%$ survival (as \% seedlings remaining in the patch and apparently pigmented and healthy) and average leaf length $(\mathrm{cm})$ for each transplant methodology and for clustered seedlings that had been planted directly in the sediment.

\section{Statistics}

Statistical design and calculations were carried out using SPSS $^{\circledR} 13.0$ for Windows ${ }^{\circledR}$ (SPSS Inc., Chicago, IL, USA). Contingency table analyses were used to detect differences on germination and further growth in 18 psu salinity and the rest of the treatments, assuming $\mathrm{H}_{0}: \mathrm{p} 1$, proportion in $18 \mathrm{psu}=\mathrm{p} 2$, proportion in other salinity treatments, and the alternative hypothesis was: $\mathrm{p} 1 \neq \mathrm{p} 2$; the test statistic was $\chi^{2}$. Bonferroni correction to the experiment-wise error rate $(5 \%)$ was applied to reduce the type 1 error rate in a set of multiple comparisons. In the outplanting experiment, ANOVA was used to compare the number of seedlings remaining each month between trays and nylon nets.

\section{Results}

We found an inverse relationship between culture medium salinity and seed germination (Table 1). The lower the salinity, the greater the germination rate. However, responses in treatments 5,11 and 18 psu were not significantly different at the end of the experiment; all salinities induced seed germination within a month. Significantly lower germination occurred in the control treatment (36 psu). Regardless of treatment, $60 \%$ of cultivated seeds germinated after three months (in $82.6 \%$ of culture vessels).

The reduced salinity treatments inhibited post-germination development (Table 1). None of the seeds germinated at 

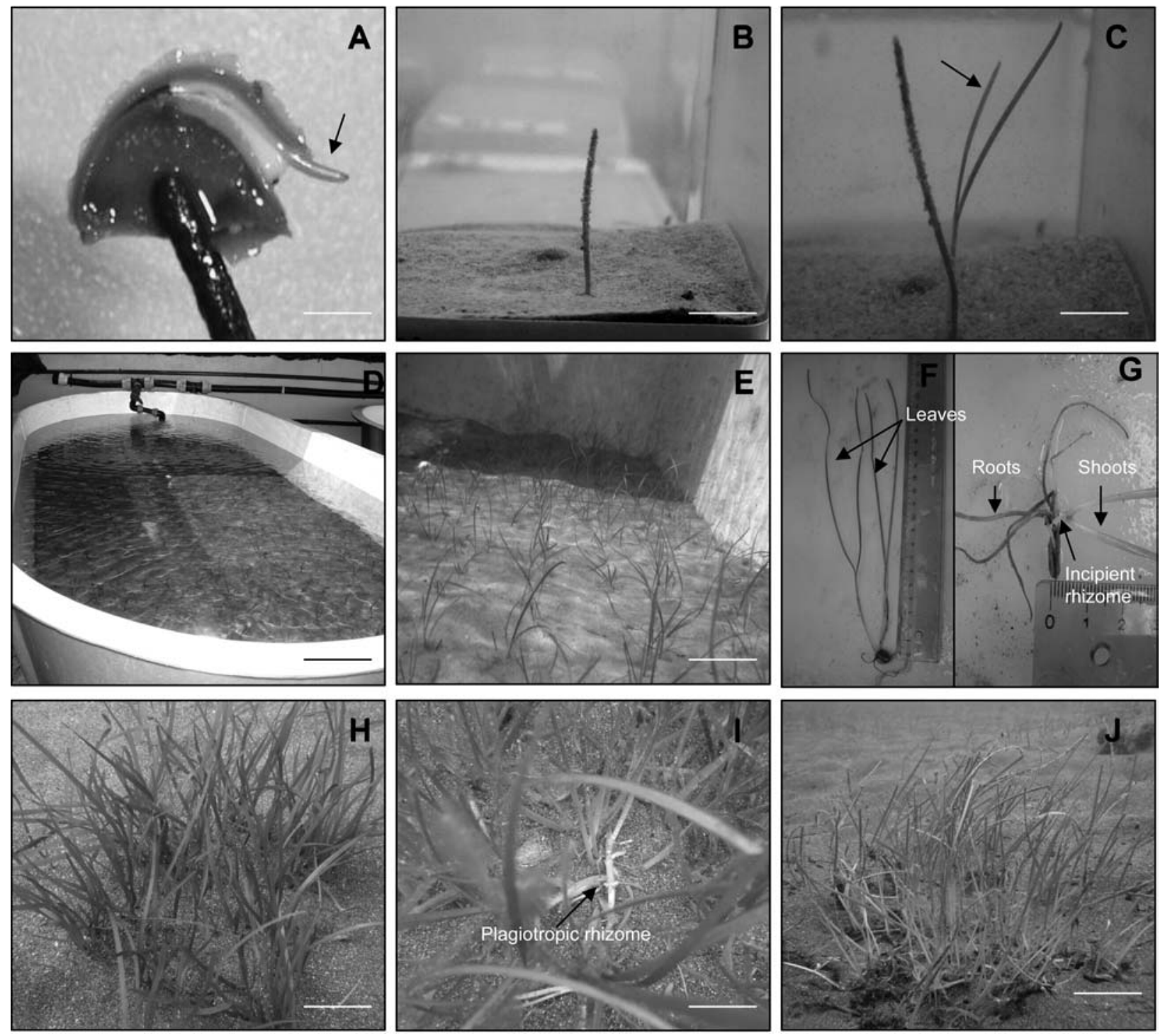

Figure 1 Cymodocea nodosa.

(A-C) Three different stages of development: (A) Stage I, germinating seeds (arrow), bar=0.5 cm; (B) Stage II, elongation of cotyledon, bar $=1 \mathrm{~cm}$; (C) Stage III, development of first new leaves (arrow), bar=1 cm; (D-G) Acclimation: (D-E) Seedlings acclimating in aquaria or tanks; (D) bar=0.5 m; (E) bar=0.4 m; $(\mathrm{F}-\mathrm{G})$ Seedlings with leaves attached to a young incipient rhizome with up to two leaves and root development after 30 days of acclimation; (H-J) Field transplant. Persistent patch formed from clustered seedlings transferred directly into the sediment: $(\mathrm{H})$ Plants at day zero, bar $=5 \mathrm{~cm}$; (I) Plants at day 30. Note plagiotropic rhizome development, bar=4 cm; (J) Plants at month 6 , bar $=5 \mathrm{~cm}$.

5 psu reached stage II and III in vitro (Figure 1B, C). Considering both germination percentage and further development up to stage III, the best germination and seedling development was achieved at salinities of 11 and 18 psu (slightly higher in the latter), as the seeds apparently acclimated in vitro and even generated two new leaves (Figure 1C).

All seeds that reached stage III developed well after transfer to continuous seawater-flow tanks (Figure 1D, E), regardless of whether or not they had germinated in media at 11 , 18 or 36 psu. Seedlings grew and developed new roots, shoots and leaves during the whole acclimation period (Figure 2A, D). At day 30, seedlings had developed 4.20 \pm 0.95 leaves, $1.40 \pm 0.50$ shoots and $4.05 \pm 1.19$ roots, with average leaf and root lengths of $22.25 \pm 6.45 \mathrm{~cm}$ and $7.46 \pm 2.90 \mathrm{~cm}$, respectively (Figure 2A-D).

After outplanting to the sea, there were no significant differences between the number of seeds surviving in trays and nylon nets until month five (Figure 3A). Thereafter, seeds attached to nets died and only few necrotic fragments remained attached, while seedlings in the trays remained (ca. $40 \%$ survival). The best results were obtained by direct transplantation into the substratum (Figure $3 \mathrm{~A}$ ). These seedlings survived a winter and are now almost a year old, forming a small patch in which new plagiotropic rhizome tissue was observed (Figure 1H-J). Leaf length was very varied when 
Table 1 Cymodocea nodosa: effect of salinity treatments on germination and further growth to reach development stage III (3 months).

\begin{tabular}{|c|c|c|c|c|c|c|c|c|c|c|c|c|}
\hline \multirow[b]{2}{*}{ Salinity (psu) } & \multicolumn{4}{|c|}{ Month 1} & \multicolumn{4}{|c|}{ Month 2} & \multicolumn{4}{|c|}{ Month 3} \\
\hline & 5 & 11 & 18 & 36 & 5 & 11 & 18 & 36 & 5 & 11 & 18 & 36 \\
\hline Germination (n) & $12^{*}$ & $12^{*}$ & 7 & - & 12 & 12 & 12 & $5 * *$ & 12 & 12 & 13 & $6 * *$ \\
\hline Germination (\%) & 92.3 & 92.3 & 53.84 & - & 92.3 & 92.3 & 92.3 & 38.46 & 92.3 & 92.3 & 100 & 46.15 \\
\hline Stage III (n) & - & 1 & 1 & - & - & 7 & 11 & $5 * *$ & - & 9 & 12 & $6^{* *}$ \\
\hline Stage III (\%) & - & 7.69 & 7.69 & - & - & 53.84 & 84.61 & 38.46 & - & 69.23 & 92.3 & 23.07 \\
\hline
\end{tabular}

Percentage germination: number of culture vessels in which germinating seeds were observed among total number of culture vessels (13 vessels per treatment; total seeds=104). Percentage stage III: number of vessels in which germinated seeds reached stage III (i.e., seedlings with one shoot and two leaves). Experiment-wise error rate is 0.05 . Comparison error rate is experiment-wise error rate/number of comparisons (Bonferroni correction). *** Indicates significant differences between a treatment and 18 psu treatment in each month $(\mathrm{p}<0.017$ and $\mathrm{p}<0.01$, respectively; - , not detected).

seedlings were transplanted into the sea, but finally stabilized at the end of the experiment (Figure 3B).

\section{Discussion}

The importance of seagrass beds has been recognised worldwide for their multiple ecological roles in estuarine and
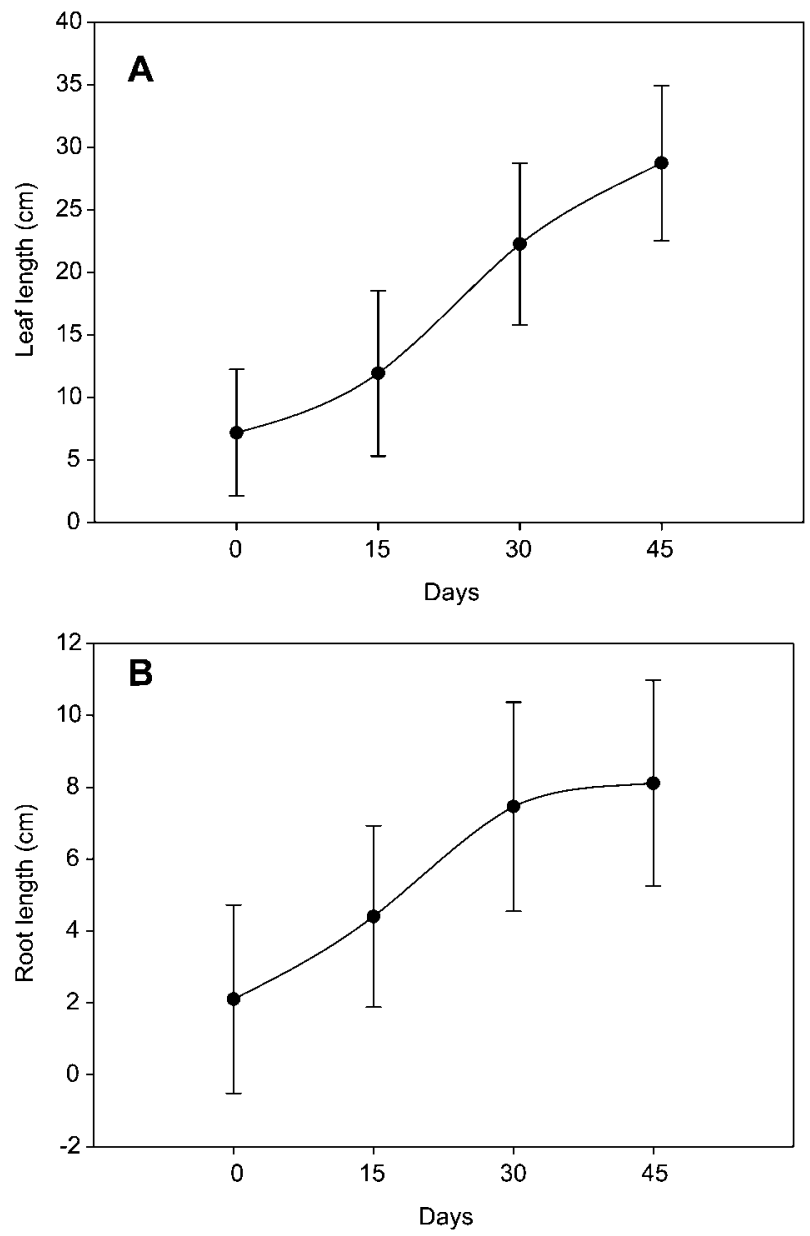

coastal systems, where they act as nursery habitat and enhance coastal erosion protection (Mena et al. 1993, Terrados and Borum 2004). However, estuaries and coasts and the species that inhabit them are vulnerable to increasing human pressure (den Hartog 1996, Orth et al. 2006, Ralph et al. 2006, Hughes et al. 2009) and habitat conditions have substantially deteriorated over the last two decades (Duarte et al. 2004). Application of diverse management strategies
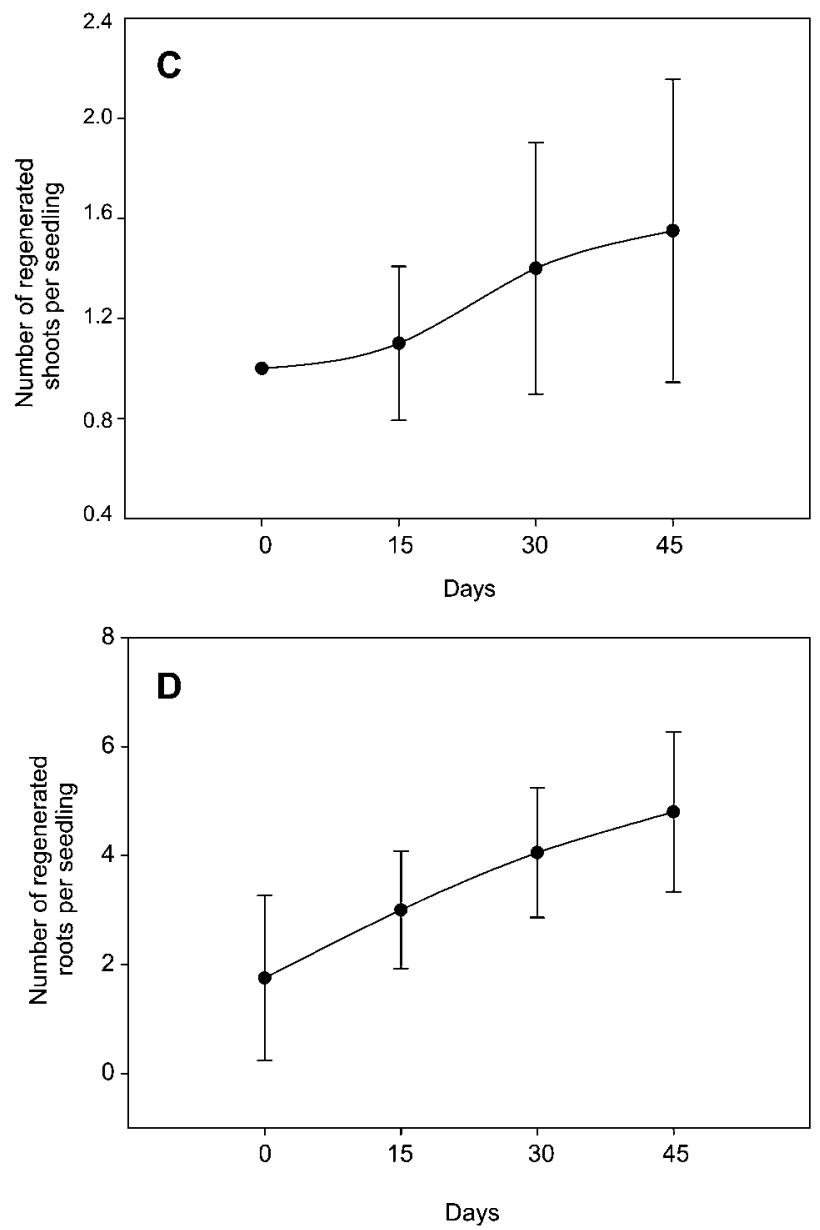

Figure 2 Cymodocea nodosa: plant development during acclimation. (A-B) Leaf and root lengths over 45 days. (C-D) Shoot and root regeneration over 45 days seedling acclimation (values are means \pm SD, $\mathrm{n}=30$ ). 

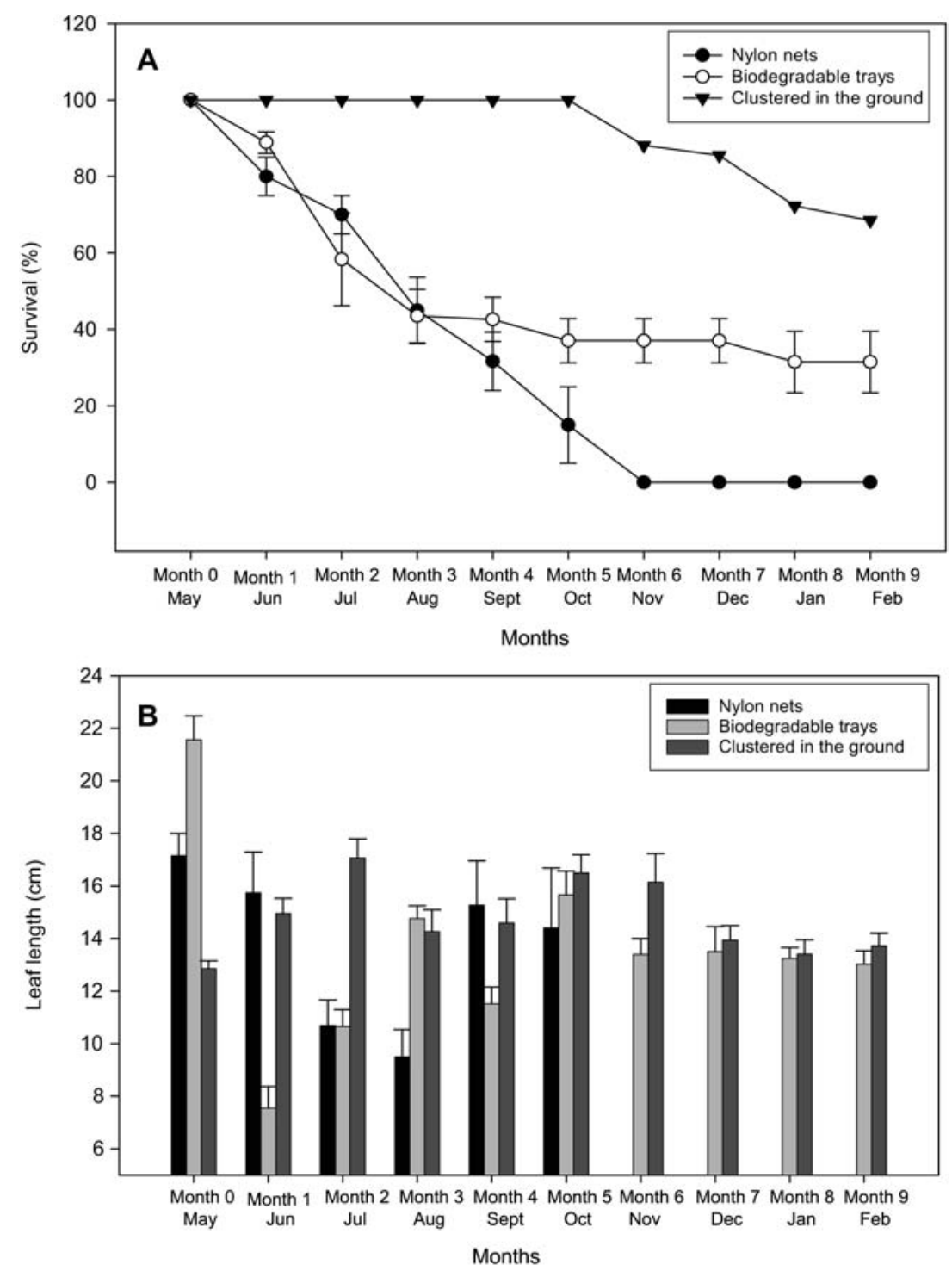

Figure 3 Cymodocea nodosa: field trials.

(A) Survival (\%). (B) Average leaf length (cm) of acclimated plantlets transferred to a natural meadow $\left(27^{\circ} 59^{\prime} 20.44^{\prime \prime} \mathrm{N} ; 15^{\circ} 22^{\prime} 12.45^{\prime \prime} \mathrm{W}\right.$, Gran Canaria, Spain) using three different transplant methodologies: a) seedlings scattered on nylon nets $(r=3, n=60)$, b) seedlings clustered in biodegradable trays $(r=3, n=108)$, and $c)$ seedlings planted directly into the sediment $(n=76)$. Seedling monitoring was performed over nine months (values are means $\pm \mathrm{SE}$ ).

for the conservation of these ecosystems is a pressing requirement (Erftemeijer et al. 2006). In Tampa Bay (Florida), control of water quality in Thalassia testudinum Banks ex Konig habitats allowed recuperation of meadows, which increased in area from 8800 ha in 1982 to 10,930 ha in 1997 (Johansson and Greening 2000). Rehabilitation, restoration and mitigation programs have been carried out worldwide with different species and with varying degrees of success (Lord et al. 1999, Fonseca et al. 2000, Van Katwijk 2003, Seddon 2004, Paling et al. 2007). As for other seagrass species, Cymodocea nodosa is affected by human impacts (Vergara-Martín et al. 2005, Fernández-Torquemada and Sánchez-Lizaso 2006), and some efforts have been made to protect and conserve them. At the present time, $C$. nodosa is included in the Catalogue of Endangered Canarian Species
(BOC 2001, decree 151/2001), and their habitat is protected by the EU in the Habitats Directive (Council Directive 92/ 43/EEC).

In this work, we have developed a propagation protocol for Cymodocea nodosa seeds that may be useful for restoration and conservation programs. The procedure includes i) germination of seeds in vitro, ii) acclimation and further growth of seedlings in tanks, and iii) their later transference to coastal marine habitats.

\section{Propagation protocol for Cymodocea nodosa}

Germination of collected seeds under hyposaline treatments In Cymodocea nodosa from the Canary Islands, optimal seed germination occurred at $50 \%$ of ambi- 
ent salinity (36 psu), although equivalent effects may be obtained with salinity as low as 11 psu. Our results are congruent with other seagrass studies that have reported hyposaline conditions to be favorable for the germination of seeds (Caye and Meinez 1986 and Caye et al. 1992 for C. nodosa; Hootsmans et al. 1987 for Zostera marina L. and for Z. noltii Hornem.; Harrison 1991 for Z. marina; Conacher et al. 1994 for Z. capricorni Aschers.; Ailstock and Shafer 2006 for Ruppia maritima L. and for Potamogeton perfoliatus L.; Alexandre et al. 2006 for Z. marina).

The number of germinated seeds eventually produced through exposure to hyposaline shock $(5,11,18 \mathrm{psu})$ was significantly higher than that in non-shocked treatments (36 psu). However, it is important to note that the highest germination rates did not necessarily provide the highest number of seedlings for further propagation. At 5 psu, Cymodocea nodosa seeds had the highest percentage germination in the first month, but further development of the seedlings was restricted at this low salinity (Table 1 ). There may be an optimal hyposaline treatment for each species that should be determined before proceeding. Moreover, temperature, light or even chemical treatments should not be disregarded as effective methods to break seed dormancy (Hilhorst and Karssen 1992). Considering both germination and seedling viability after hyposaline treatment, 11 and 18 psu (slightly better at the higher salinity) appeared to be suitable for further seedling propagation. The germination of seeds in enriched seawater (modified PES) and 50\% of normal salinity, with further salinity increases to 36 psu after 30 days in culture, supported a transition rate of 54\% from germination to stage III of development (92.3\% germinated individuals reached stage III of development, Figure 1C).

Acclimation of germinated seeds in tanks Acclimation is considered a mandatory step when propagating terrestrial plants using in vitro techniques, since plants derived from cell cultures under controlled conditions may be shocked when transferred directly to the field (Pospíšilová et al. 1999). The acclimation of seagrass seedlings to optimize transplantation survival and growth has been emphasized in previous work (Meinesz et al. 1993, Bird et al. 1994, Woodhead and Bird 1998). However, it is also important to use the minimum feasible acclimation-period to make the protocol more cost-effective. For this reason, we consider a 30day period sufficient to produce healthy Cymodocea nodosa seedlings (100\% of germinated seed) ready for transplantion to the natural environment (Figure 1F). By this time, we had produced seedlings with up to four leaves $(>20 \mathrm{~cm}$ long) and substantial root development (up to four single roots and $7 \mathrm{~cm}$ long) (Figures 1F, G and 2).

Even though previous authors have germinated Cymodocea nodosa seeds under laboratory conditions (Caye and Meinesz 1986, Caye et al. 1992), further growth in these earlier works was limited, with seedling death after three to four months (Pirc et al. 1986, Buia and Mazzella 1991). The propagation systems used in our work (see Materials and methods) allow germination and continuous growth of seed- lings, producing healthy plants ready for transplant in a fourmonth period.

Field transplants Use of seeds and seedlings in restoration programs has been considered as a cost effective technique that could introduce genetic variability into damaged meadows (Orth et al. 2000, Procaccini and Piazzi 2001, Ailstock and Shafer 2006). Previous works on seedling transplantation have experienced problems with anchoring, and different attachment protocols have been developed to settle seedlings into the sediment (Meinesz et al. 1993, Kirkman 1998, Woodhead and Bird 1998, Seddon et al. 2004, Wear et al. 2006). Perhaps unexpectedly, our results suggest that anchoring of seedlings and plantlets might not be so critical for Cymodocea nodosa when seedlings are transplanted to a sheltered place without any anchoring method, as seen for seedlings directly planted into the sediment (Figure 3A). These seedlings developed plagiotropic rhizomes one month after transplantation (Figure 1I). According to Kirkman (1998) and Marbá et al. (2004), the development of plagiotropic rizhomes signifies the establishment of vegetative clonal growth necessary for the formation of new patches. This predicts great success for the future survival of transplanted seedlings; Marbá et al. (2004) reported that 50-70\% of seagrass seedlings die in nature before clonal growth begins. Furthermore, clonal growth allows the accumulation of carbon and mineral nutrients to maintain growth in unfavorable seasons and for resource allocation in the face of tissue loss to grazing (Vergés et al. 2008).

Our field observations (i.e., bites on the leaf) pointed to herbivory as a possible explanation for the highly variable leaf lengths observed in transplanted seedlings (Figure 3B). We believe that clustered seedlings in the field and the resulting development of plagiotropic rhizome may also have mitigated herbivore attack, as was the case for Posidonia sp. in Western Australia (Kirkman 1998). This may help explain higher success when seedlings were clustered at an initial density of $\sim 3000 \mathrm{~s} \mathrm{~m}^{-2}$ (i.e., in trays and direct transplanting methods, Figure 3A).

\section{Acknowledgements}

This work was supported by the Autonomous Government of the Canary Islands (Plan de Restauración de Sebadales de Canarias), which also provided a scholarship for M.E. Zarranz. We thank Dr. Mark Fonseca (NOAA) and Dr. Eric Bunn (KPBG) for their critical reviews of this manuscript.

\section{References}

Addy, C.E. 1947. Eelgrass planting guide. Mar. Conserv. 24: 16-17. Ailstock, S. and D. Shafer. 2006. Protocol for large-scale collection, processing, and storage of seeds of two mesohaline submerged aquatic plant species. ERDC/TN SAV-06-3, U.S. Army Engineer Research and Development Center, Vicksburg, MS. p. 8.

Alberto, F., S. Massa, P. Manent, E. Diaz-Almela, S. Arnaud-Haond, C.M. Duarte and E.A. Serrão. 2008. Genetic differentiation and secondary contact zone in the seagrass Cymodocea nodosa 
across the Mediterranean-Atlantic transition zone. J. Biogeography 35: 1270-1294.

Alexandre, A., S. Cabaço, R. Santos and E.A. Serrão. 2006. Timing and success of reproductive stages in the seagrass Zostera noltii. Aquat. Bot. 85: 219-223.

Balestri, E., L. Piazzi and F. Cinelli. 1998. Survival and growth of transplanted and natural seedlings of Posidonia oceanica (L.) Delile in a damaged coastal area. J. Exp. Mar. Biol. Ecol. 228: 209-225.

Bird, K.T., J. Jewett-Smith and M.S. Fonseca. 1994. Use of in vitro - propagated Ruppia maritima for sea meadow restoration. J. Coast. Res. 10: 732-737.

Buia, M.C. and L. Mazzella. 1991. Reproductive phenology of the Mediterranean seagrasses Posidonia oceanica (L.) Delile, Cymodocea nodosa (Ucria) Aschers, and Zostera noltii Hornem. Aquat. Bot. 40: 343-362.

Caye, G. and A. Meinesz. 1985. Observations on the vegetative development, flowering and seeding of Cymodocea nodosa (Ucria) Ascherson, on the Mediterranean coast of France. Aquat. Bot. 22: 277-289.

Caye, G. and A. Meinesz. 1986. Experimental study of seed germination in the seagrass Cymodocea nodosa. Aquat. Bot. 26: $79-87$.

Caye, G., C. Bulard, A. Meinesz and F. Loquès. 1992. Dominant role of seawater osmotic pressure on germination in Cymodocea nodosa. Aquat. Bot. 42: 187-193.

Christensen, P.B., E. Diaz-Almela and O. Diekmann. 2004. Can transplanting accelerate the recovery of seagrasses? In: (J. Borum, C.M. Duarte, D. Krause-Jensen and T.M. Greve, eds) European seagrasses: an introduction to monitoring and management. The M \& MS project, Copenhagen. pp. 77-82.

Conacher, C.A., I.R. Poiner, J. Butler, S. Pun and D.J. Tree. 1994. Germination, storage and viability testing of seeds of Zostera capricorni Aschers. from a tropical bay in Australia. Aquat. Bot. 49: 47-58.

Cunha, A. and A. Araújo. 2009. New distribution limits of seagrass beds in West Africa. J. Biogeogr. 36: 1621-1622.

Curiel, D., F. Scarton, A. Rismondo and M. Marzocchi. 2003. Transplanting seagrasses in the Venice Lagoon: results and perspectives. In: (E. Orzhan, ed) Proceedings of the Sixth International Conference on the Mediterranean Coastal Environment, MEDCOAST 03. Medcoast publications, Ankara. pp. 7-11.

den Hartog, C. 1996. Sudden declines of seagrass beds: "wasting disease" and other disasters. In: (J. Kuo, R.C. Phillips, D.L. Walker and H. Kirkman, eds). Seagrass biology: proceedings of an international workshop. Faculty of Sciences, University of Western Australia, Perth. pp. 307-314.

Duarte, C.M. and J.P. Gattuso. 2008. Seagrass meadows. In: (C.J. Cleveland, ed). Encyclopedia of earth. Environmental Information Coalition, National Council for Science and the Environment, Washington, D.C. (First published in the Encyclopedia of Earth December 11, 2006; last revised September 21, 2008; retrieved February 24, 2010). http://www.eoearth.org/article/ Seagrass_meadows.

Duarte, C.M., N. Marbà and R. Santos. 2004. What may cause loss of seagrasses? In: (J. Borum, C.M. Duarte, D. Krause-Jensen and T.M. Greve, eds) European seagrasses: an introduction to monitoring and management. The M \& MS project, Copenhagen. pp. 24-33.

Erftemeijer, P.L.A., M.C. Gambi and C. Pergent-Martini. 2006. Conservation of Mediterranean marine vegetation. Biol. Mar. Medit. 13: $290-293$.

Fernández Torquemada, Y. and J.L. Sánchez Lizaso. 2006. Effects of salinity on growth and survival of Cymodocea nodosa (Ucria)
Ascherson and Zostera noltii Hornemann. Biol. Mar. Med. 13: 46-47.

Fonseca, M.S., W.J. Kenworthy and G.W. Thayer. 1998. Guidelines for the conservation and restoration of seagrasses in the United States and adjacent waters. NOAA Coastal Ocean Program Decision Analysis Series No. 12. NOAA. Coastal Ocean Office, Silver Spring, MD. p. 222.

Fonseca, M.S., B.E. Julius and W.J. Kenworthy. 2000. Integrating biology and economics in seagrass restoration: how much is enough and why? Ecol. Eng. 15: 227-237.

García-Jiménez, P., E. Navarro, C. Santana, A. Luque and R.R. Robaina. 2006. Anatomical and nutritional requirements for induction and sustained growth in vitro of Cymodocea nodosa (Ucria) Ascherson. Aquat. Bot. 84: 79-84.

Gordon, D.M. 1996. Status of seagrass restoration: review of international literature. Report to Cockburn Cement Limited. Le Provost Dames \& Moore, South Perth, Australia. p. 41.

Granger, S., M. Traber, S.W. Nixon and R. Keyes. 2002. A practical guide for the use of seeds in eelgrass (Zostera marina L.) restoration. I. Collection, processing, and storage. Rhode Island Sea Grant, Narragansett, RI. p. 20.

Harrison, P.G. 1991. Mechanisms of seed dormancy in an annual population of Zostera marina (eelgrass) from the Netherlands. Can. J. Bot. 69: 1972-1976.

Harwell, M.C. and R.J. Orth. 1999. Eelgrass (Zostera marina L.) seed protection for field experiments and implication for large scale restoration. Aquat. Bot. 64: 51-61.

Heidelbaugh, W.S., L.M. Hall, W.J. Kenworthy, P. Whitfield, R.W. Virnstein, L.J. Morris and M.D. Hanisak. 2000. Reciprocal transplanting of the threatened seagrass Halophila johnsonii (Johnson's Seagrass) in the Indian River lagoon, Florida. In: (S.A. Bortone, ed). Seagrasses: monitoring, ecology, physiology, and management. CRC Press, Boca Raton, FL. pp. 197-210.

Hilhorst, H.W.M. and C.M. Karssen. 1992. Seed dormancy and germination: the role of abscisic acid and gibberellins and the importance of hormone mutants. Plant Growth Reg. 11: 225238.

Hootsmans, M.J.M., J.E. Vermaat and W. van Vierssen. 1987. Seedbank development, germination and early seedling survival of two seagrass species from the Netherlands: Zostera marina L. and Zostera noltii Hornem. Aquat. Bot. 28: 275-285.

Hughes, A.R., S.L. Williams, C.M. Duarte, L.H. Kenneth Jr. and M. Waycott. 2009. Associations of concern: declining seagrasses and threatened dependent species. Front. Ecol. Environ. 7: 242246.

Johansson, J.O.R. and H.S. Greening. 2000. Seagrass restoration in Tampa Bay: a resource-based approach to estuarine management. In: (S.A. Bortone, ed). Seagrasses: monitoring, ecology, physiology, and management. CRC Press, Boca Raton, FL. pp. 279-293.

Kirkman, H. 1998. Pilot experiments on planting seedlings and small seagrass propagules in Western Australia. Mar. Poll. Bull. 37: 460-467.

Lord, D., E. Paling and D. Gordon. 1999. Review of Australian rehabilitation and restoration programs. In: (A.J. Butler and P. Jernakoff, eds) Seagrass in Australia: strategic review and development of an $R$ and $D$ plan. CSIRO Publishing, Collingwood, Victoria. pp. 65-115.

Marbà, N., C.M. Duarte, A. Alexandra and S. Cabaço. 2004. How do seagrasses grow and spread? In: (J. Borum, C.M. Duarte, D. Krause-Jensen and T.M. Greve, eds) European seagrasses: an introduction to monitoring and management. The M\&MS project, Copenhagen. pp. 11-19. 
Meinesz, A., G. Caye, F. Loques and H. Molenaar. 1993. Polymorphism and development of Posidonia oceanica transplanted from different parts of the Mediterranean into the National Park of Port-Cross. Bot. Mar. 36: 209-216.

Mena, J., J.M. Falcón, A. Brito, F.M. Rodríguez and M. Mata. 1993. Catálogo preliminar de la ictiofauna de las praderas de fanerógamas marinas de la isla de Tenerife, Islas Canarias. Publ. Espec. Inst. Esp. Oceanogr. 11: 217-222.

Orth, R.J., M. Luckenbach and K.A. Moore. 1994. Seed dispersal in a marine macrophyte: implications for colonization and restoration. Ecology 75: 1927-1939.

Orth, R.J., M.C. Harwell and J.R. Fishman. 1999. A rapid and simple method for transplanting eelgrass using single, unanchored shoots. Aquat. Bot. 64: 77-85.

Orth, R.J., M.C. Harwell, E.M. Bailey, A. Bartholomew, J.T. Jawad, A.V. Lombana, K.A. Moore, J.M. Rhode and H.E. Woods. 2000. A review of issues in seagrass seed dormancy and germination: implications for conservation and restoration. Mar. Ecol. Prog. Ser. 200: 277-288.

Orth, R.J., T.J.B. Carruthers, W.C. Dennison, C.M. Duarte, J.W. Fourqurean, W. James, H.K. Heck Jr, A.R. Hughes, G.A. Kendrick, W.J. Kenworthy, S. Olyarnik, F.T. Short, M. Waycott and S.L. Williams. 2006. A global crisis for seagrass ecosystems. Bioscience 56: 987-996.

Orth, R.J., S.R. Marion, S. Granger and M. Traber. 2009. Evaluation of a mechanical seed planter for transplanting Zostera marina (eelgrass) seeds. Aquat. Bot. 90: 204-208.

Paling, E.I, M. Van Keulen and D.J. Tunbridge. 2007. Seagrass transplanting in Cockburn Sound, Western Australia: a comparison of manual transplantation methodology using Posidonia sinuosa Cambridge et Kuo. Rest. Ecol. 15: 240-249.

Park, J.I. and K.S. Lee. 2007. Site-specific success of three transplanting methods and the effect of planting time on the establishment of Zostera marina transplants. Mar. Poll. Bull. 54: 1238-1248.

Pavón-Salas, N., R. Herrera, A. Hernández-Guerra and R. Haroun. 2000. Distribution pattern of seagrasses in the Canary Islands (Central-East Atlantic Ocean). J. Coast. Res. 16: 329-335.

Phillips, R.C. 1974. Transplantation of seagrasses, with special emphasis on eelgrass, Zostera marina L. Aquaculture 4: 161176.

Pickerell, C.H., S. Schott and S. Wyllie Echeverria. 2005. Buoy deployed seeding: demonstration of a new eelgrass (Zostera marina L.) planting method. Ecol. Eng. 25: 127-136.

Pirc, H., M.C. Buia and L. Mazzella. 1986. Germination and seedling development of Cymodocea nodosa (Ucria) Aschers. under laboratory conditions. Aquat. Bot. 26: 181-188.

Pospísilová, J., I. Tichá, P. Kadleček, D. Haisel and S. Plzáková. 1999. Acclimatization of micropropagated plants to ex vitro conditions. Biol. Plant. 42: 481-497.

Procaccini, G. and L. Piazzi. 2001. Genetic polymorphism and transplantation success in the Mediterranean seagrass Posidonia oceanica. Restor. Ecol. 9: 332-338.

Provasoli, L. 1968. Media and prospects for cultivation of marine algae. In: (A. Watanabe and A. Hattori, eds). Cultures and collections of algae. The Japanese Society of Plant Physiologists, Tokyo. pp. 47-74.

Ralph, P.J., D. Tomasko, K. Moore, S. Seddon and C.M.O. Macinnis-Ng. 2006. Human impacts on seagrasses: eutrophication, sedimentation, and contamination. In: (A.W.D. Larkum, R.J. Orth and C.M. Duarte, eds). Seagrasses: biology, ecology and conservation. Springer, Dordrecht. pp. 567-593.

Reusch, T.B.H. 2002. Microsatellites reveal high population con- nectivity in eelgrass (Zostera marina) in two contrasting coastal areas. Limn. Oceanog. 47: 78-85.

Reyes, J., M. Sansón and J. Afonso-Carrillo. 1995. Distribution and reproductive phenology of the seagrass Cymodocea nodosa (Ucria) Ascherson in the Canary Islands. Aquat. Bot. 50: 171180.

Robaina, R.R., G. García Reina and A. Luque. 1990a. The effects of the physical characteristics of the culture medium on the development of red seaweeds in tissue culture. Hydrobiologia 204/205: 137-142.

Robaina, R.R., P. García, G. García Reina and A. Luque. 1990 b. Morphogenetic effect of glycerol on tissue cultures of the red seaweed Grateloupia doryphora. J. Appl. Phycol. 2: 137143.

Ruiz de la Rosa, M., N. Garcia, M. Zarranz, P. Manent, R. Domínguez, M. Grimon, G. Louzara and N. Gonzalez. 2006. Preliminary results of experimental evaluation about different methods of transplanting Cymodocea nodosa in the Canary Islands. Biol. Mar. Med. 13: 267-271.

Seddon, S. 2004. Going with the flow: facilitating seagrass rehabilitation. Ecol. Manag. Restor. 5: 167-176.

Seddon, S., S. Venema and D. Millar. 2004. Seagrass rehabilitation in Metropolitan Adelaida. II. Donor bed independent methods progress report. Progress report to the coast protection branch. Department for Environment and Heritage. SARDI Aquatic Sciences, Adelaide.

Terrados, J. 1993. Sexual reproduction and seed banks of Cymodocea nodosa (Ucria) Ascherson meadows on the southeast Mediterranean coast of Spain. Aquat. Bot. 46: 293-299.

Terrados, J. and J. Borum. 2004. Why are seagrasses important? Goods and services provided by seagrass meadows. In: (J. Borum, C.M. Duarte, D. Krause-Jensen and T.M. Greve, eds) European seagrasses: an introduction to monitoring and management. The M \& MS project, Copenhagen. pp. 8-11.

Terrados, J. and J.D. Ross. 1995. Temperature effects on photosynthesis and depth distribution of the seagrass Cymodocea nodosa (Ucria) Ascherson in a Mediterranean coastal lagoon: the Mar Menor (SE Spain). PSZNI Mar. Ecol. 16: 133-144.

Thorhaug, A. 1985. Large-scale seagrass restoration in a damaged estuary. Mar. Poll. Bull. 16: 55-62.

Van Katwijk, M.M. 2003. Reintroduction of eelgrass (Zostera mari$n a$ L.) in the Dutch Wadden Sea; a research overview and management vision. In: (W.J. Wolff, K. Essink, A. Kellermann and M.A. van Leeuwe, eds). Challenges to the Wadden Sea area. Proceedings of the 10th International Scientific Wadden Sea Symposium. Ministry of Agriculture, Nature Management and Fisheries and Dept. of Marine Biology University of Groningen. pp. 173-197.

Van Keulen, M., E.I. Paling and C.J. Walker. 2003. Effect of planting unit size and sediment stabilization on seagrass transplants in Western Australia. Rest. Ecol. 11: 50-55.

Vergara-Martín, J.M., R. Haroun Tabraue and M.N. González Henríquez (eds.). 2005. Evaluación de impacto ambiental de acuicultura en Jaulas en Canarias. Oceanográfica, Telde, 110 pp.

Vergés, A., M. Pérez, T. Alcoverro and J. Romero. 2008. Compensation and resistance to herbivory in seagrasses: induced responses to simulated fish consumption. Oecologia 155: 751760.

Walker, D.I. and A.J. McComb. 1992. Seagrass degradation in Australian coastal waters. Mar. Poll. Bull. 25: 191-195.

Waycott, M. 1995. Assessment of genetic variation and clonality in the seagrass Posidonia australis using RAPD and allozyme analysis. Mar. Ecol. Prog. Ser. 116: 289-295. 
Wear, R.J., J.T. Tanner and S. Venema. 2006. Seagrass rehabilitation in metropolitan Adelaide III: Development of recruitment facilitation methodologies. Prepared for the Coastal Protection Branch, Department for Environment and Heritage. SARDI Aquatic Sciences Publication No.04/0038-3. SARDI, Aquatic Sciences, Adelaide.

Williams, S.L. and R.J. Orth. 1998. Genetic diversity and structure of natural and transplanted eelgrass populations in the Chesapeake and Chincoteague Bays. Estuaries 21: 118-128.

Woodhead, J.L. and K.T. Bird. 1998. Efficient rooting and acclimation of micropropagated Ruppia maritima Loisel. J. Mar. Biotech. 6: 152-156.

Received 16 August, 2009; accepted 6 January, 2010 